\title{
Stereoselective synthesis of jaspine B from D-xylose
}

\author{
Jun Liu, ${ }^{a}$ Yuguo Du, ${ }^{\mathrm{a}, *}$ Xiaomin Dong, ${ }^{\mathrm{b}}$ Shucong Meng, ${ }^{\mathrm{b}}$ Junjun Xiao ${ }^{\mathrm{b}}$ and Lijian Cheng ${ }^{\mathrm{c}}$ \\ ${ }^{a}$ State Key Laboratory of Environmental Chemistry and Ecotoxicology, Research Center for Eco-Environmental Sciences, \\ Chinese Academy of Sciences, Beijing 100085, China \\ ${ }^{\mathrm{b}}$ Department of Cell Biology, Basic Medicinal College, Peking University Health Science Center, Beijing 100083, China \\ ${ }^{\mathrm{c}}$ School of Chemical and Environmental Engineering, China University of Mining and Technology-Beijing, Beijing 100083, China
}

Received 25 June 2006; received in revised form 7 August 2006; accepted 10 August 2006

Available online 14 September 2006

\begin{abstract}
The natural cytotoxic marine compound, jaspine B, is stereoselectively synthesized from D-xylose in 11 linear steps with a $23.9 \%$ overall yield. The key step in the synthesis involves an iodine-induced debenzylation of a primary alcohol and the subsequent 2,5-cyclization to fit the required configuration of jaspine B. A preliminary bioassay shows strong inhibition activities against human MDA231, Hela, and CNE cell lines, indicating potential usage in various cancer treatments.

(C) 2006 Elsevier Ltd. All rights reserved.
\end{abstract}

Keywords: Natural products; Jaspine B; Antitumor activity; Carbohydrates; Total synthesis

\section{Introduction}

Phytosphingosine is involved in several biological processes, including heat-stress response and endocytic events. ${ }^{1}$ Further studies revealed that sphingosine 1phosphate induces a rapid and relevant release of arachidonic acid, and increases phospholipase D activity in A549 cells. ${ }^{2}$ Phytosphingosine is also found to be a key intermediate from which more complex metabolites are derived. ${ }^{3}$ Apart from the linear structures, phytosphingosine derivatives also exist as anhydro forms that were shown to be potent inhibitors of a variety of glycosidase activities. ${ }^{4}$ Jaspine B (1, Scheme 1), one of the natural occurring anhydrophytosphingosine derivatives, was isolated from marine sponges, Pachastrissa sp. and Jaspis sp., ${ }^{5}$ and exhibited a significant cytotoxicity against P388, A549, HT29, and MEL28 carcinoma cell lines in vitro. ${ }^{6}$ High-resolution NMR and mass spectral analyses, as well as chemical derivatization studies suggested an all-syn trisubstituted tetrahydrofuran framework, and the $(2 S, 3 S, 4 S)$ absolute configuration of jaspine B. The impressive biological activity and

\footnotetext{
* Corresponding author. Tel.: +86 10 62914475; fax: +86 10 62923563; e-mail: duyuguo@rcees.ac.cn
}

novel structural features have encouraged several research groups to explore the preparation of this compound. ${ }^{7}$ To improve our understanding of this anhydrosphingosine and its targeting to tumor cells and to lay the groundwork for more potent analogues based on this novel structure, we launched a stereoselective total synthesis of natural jaspine B. We report herein a practical synthesis of jaspine B using D-xylose as the chiral starting material, and a preliminary bioassay against human MDA231, Hela, and CNE cell lines.

\section{Results and discussion}

We have previously accomplished the total synthesis of jaspine $\mathrm{B}^{7 \mathrm{~d}}$ To provide more samples for bioactivity research, we enlarged the reaction scale $(10 \mathrm{~g})$ and unexpectedly found that the conversion of mesylate into azido intermediate in the presence of $\mathrm{C}-1$ diethylacetal group was quite slow. To explore a more practical method toward jaspine B preparation, we designed the following strategy as shown in Scheme 1.

$3,5-\mathrm{Di}-O$-benzyl- $\alpha$-D-xylofuranose (3) was easily obtained from D-xylose (2) through a three-step reaction in a $72 \%$ overall yield. ${ }^{8}$ Oxidation of diol 3 with $\mathrm{NaIO}_{4}$ 


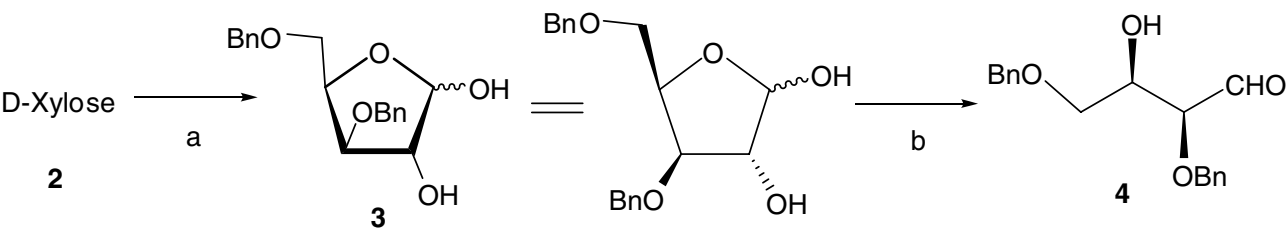

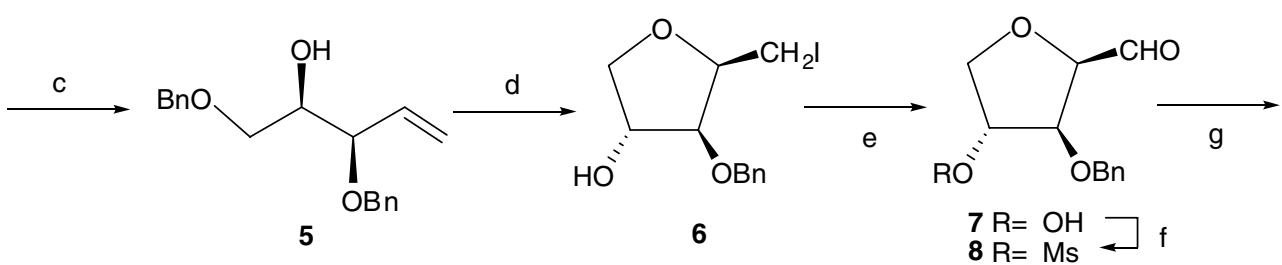<smiles>CCCCC1OC[C@@H](OC)C1OCc1ccccc1</smiles>

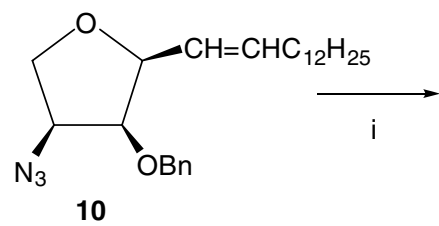

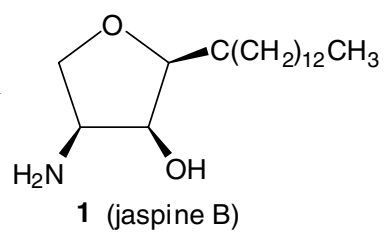

Scheme 1. Total synthesis of jaspine B. Reagents and conditions: (a) Ref. 8, 72\% in three steps; (b) $\mathrm{NaIO}_{4}, \mathrm{MeOH} \mathrm{H}_{2} \mathrm{O} ;(\mathrm{c}) \mathrm{CH}_{3} \mathrm{Ph}_{3} \mathrm{P}^{+} \mathrm{Br}^{-}, \mathrm{BuLi}$, dry THF, $-40{ }^{\circ} \mathrm{C}$ to rt, $82 \%$ for two steps; (d) $\mathrm{I}_{2}, \mathrm{NaHCO}_{3}, \mathrm{CH}_{3} \mathrm{CN}, 80 \%$; (e) $\mathrm{NaHCO}_{3}$, dry DMSO, $150{ }^{\circ} \mathrm{C}, 6 \mathrm{~min}$; (f) $\mathrm{MsCl}, \mathrm{Py}, \mathrm{rt}, 30 \mathrm{~min}, 74 \%$ for two steps; (g) $\mathrm{C}_{13} \mathrm{H}_{27} \mathrm{Ph}_{3} \mathrm{P}^{+} \mathrm{Br}^{-}$, BuLi, dry THF, $-40{ }^{\circ} \mathrm{C}$ to rt, $90 \%, Z / E$ ratio $>10 / 1$; (h) $\mathrm{NaN}_{3}, \mathrm{NH}_{4} \mathrm{Cl}, \mathrm{DMF}, 120{ }^{\circ} \mathrm{C}, 20 \mathrm{~h}, 80 \%$; (i) $\mathrm{Pd} / \mathrm{C}, \mathrm{H}_{2}$, $\mathrm{MeOH}$, TFA, 5 h, $95 \%$.

in methanol ${ }^{9}$ gave $(2 S, 3 R)$-2,4-bis(benzyloxy)-3-hydroxybutanal (4), which was directly subjected to a Wittig reaction with $\mathrm{Ph}_{3} \mathrm{P}=\mathrm{CH}_{2}$ and gave $(2 R, 3 R)$-1,3-di- $O$ benzyl-4-pentene-1,2,3-triol (5) in an $82 \%$ yield (Scheme 1). An iodine-induced consecutive cyclization/benzyl deprotection was carried out smoothly in anhyd acetonitrile in the presence of $\mathrm{I}_{2}$ and $\mathrm{NaHCO}_{3},{ }^{10}$ affording iodide $6(80 \%)$, which was further transformed into $(2 R, 3 S, 4 R)$-3-(benzyloxy)-4-hydroxytetrahydrofuran2-carbaldehyde (7) with dimethyl sulfoxide. ${ }^{11}$ On treatment of crude 7 with methanesulfonyl chloride in pyridine we obtained $(2 R, 3 S, 4 R)$-3-(benzyloxy)-4-methanesulfonyloxytetrahydrofuran-2-carbaldehyde (8) in a $74 \%$ isolated yield. The standard Wittig olefination of 8 with a C-13 alkyl donor resulted in the incorporation of an inseparable mixture of (3R,4R,5S)-4-(benzyloxy)5-((E,Z)-tetradec-1-enyl)tetrahydrofuran-3-yl methanesulfonate $(9,90 \%$ yield) with the corresponding C-14 olefinic side chain. The $Z / E$ ratio was determined to be greater than 10:1 based on ${ }^{1} \mathrm{H}$ NMR spectroscopy, but both could be further reduced to the desired alkyl side chain. The $\mathrm{S}_{\mathrm{N}} 2$ substitution of 9 with $\mathrm{NaN}_{3}$ in DMF gave $(2 S, 3 S, 4 S)$-4-azido-3-(benzyloxy)-2-((E,Z)tetradec-1-enyl)tetrahydrofuran (10) in an $80 \%$ yield. A single step hydrogenation of the azido and benzyl groups, and the side-chain double bond in methanol (containing 1\% TFA) furnished target molecule, jaspine B (1), in a salt form in an excellent yield of $95 \%$.

The effects of jaspine B against human MDA231, $\mathrm{CNE}$, and Hela cell growth were investigated based on Higa's method. ${ }^{6 a}$ Jaspine B significantly inhibited the proliferation of human MDA231 cell lines with $\mathrm{IC}_{50}$ $0.52,0.37$, and $0.1 \mu \mathrm{g} / \mathrm{mL}$ corresponding to the treatments of 24, 48, and $72 \mathrm{~h}$, respectively. For human CNE cell lines, the $\mathrm{IC}_{50}$ s were 0.78 and $0.005 \mu \mathrm{g} / \mathrm{mL}$ corresponding to 48 and $72 \mathrm{~h}$, while human Hela cell lines had an $\mathrm{IC}_{50} 0.79 \mu \mathrm{g} / \mathrm{mL}$ at $72 \mathrm{~h}$. The results are summarized in Table 1.

In conclusion, utilizing a chiral-pool strategy based on D-xylose as the starting material, the stereoselective total synthesis of a structurally unique bioactive anhydrosphingosine natural product, jaspine $\mathrm{B}$, has been

Table 1. Effect (inhibition rate, \%) of jaspine B on the growth of human MDA231, CNE, and HeLa cells

\begin{tabular}{|c|c|c|c|c|c|c|c|c|c|c|}
\hline \multirow[t]{2}{*}{ Groups } & \multirow[t]{2}{*}{ Dose $(\mu \mathrm{g} / \mathrm{mL})$} & \multicolumn{3}{|c|}{ MDA231 } & \multicolumn{3}{|c|}{ Hela } & \multicolumn{3}{|c|}{$\mathrm{CNE}$} \\
\hline & & $24 \mathrm{~h}$ & $48 \mathrm{~h}$ & $72 \mathrm{~h}$ & $24 \mathrm{~h}$ & $48 \mathrm{~h}$ & $72 \mathrm{~h}$ & $24 \mathrm{~h}$ & $48 \mathrm{~h}$ & $72 \mathrm{~h}$ \\
\hline \multirow[t]{4}{*}{ Jaspine B } & 0.005 & 16 & 26 & 37 & 4 & 0 & 42 & 0 & 0 & 49 \\
\hline & 0.01 & 12 & 35 & 44 & 0 & 17 & 45 & 0 & 19 & 69 \\
\hline & 0.1 & 35 & 32 & 51 & 20 & 27 & 42 & 0 & 23 & 73 \\
\hline & 1 & 67 & 93 & 95 & 45 & 35 & 52 & 43 & 59 & 86 \\
\hline CDDP & 3 & 35 & 28 & 32 & 27 & 15 & 59 & 0 & 37 & 68 \\
\hline Control & 0 & 0 & 0 & 0 & 0 & 0 & 0 & 0 & 0 & 0 \\
\hline
\end{tabular}


achieved in 11 linear steps and a $23.9 \%$ overall yield. The key step in the synthesis involves an iodine-induced debenzylation on primary alcohol and the subsequent 2,5-cyclization to fit the required configuration toward jaspine B. A preliminary bioassay shows that jaspine B presents strong inhibition activities against human MDA231, Hela, and CNE cell lines, indicating potential usage in various cancer treatments. The current report provides an alternative way for the preparation of the antitumor agent jaspine B, and the method should be valuable in the preparation of other tetrahydrofuran derivatives. $^{12}$

\section{Experimental}

\subsection{General methods}

Optical rotations were determined at $25^{\circ} \mathrm{C}$ with a Perkin-Elmer Model 241-Mc automatic polarimeter, and $[\alpha]_{D^{-v a l u e s}}$ are in units of $10^{-1} \mathrm{deg} \mathrm{cm}^{2} \mathrm{~g}^{-1}$. The ${ }^{1} \mathrm{H}$ and ${ }^{13} \mathrm{C}$ NMR spectra were recorded with a Bruker ARX 400 spectrometer for solutions in $\mathrm{CDCl}_{3}$ or $\mathrm{CD}_{3} \mathrm{OD}$. Chemical shifts are given in parts per million downfield from internal $\mathrm{Me}_{4} \mathrm{Si}$. Mass spectra were measured using a JEOL JMS-700 mass spectrometer. Thinlayer chromatography (TLC) was performed on silica gel $\mathrm{HF}_{254}$ with detection by charring with $30 \%(\mathrm{v} / \mathrm{v})$ $\mathrm{H}_{2} \mathrm{SO}_{4}$ in $\mathrm{MeOH}$, or in some cases by a UV lamp. Column chromatography was conducted by elution of a column of silica gel (100-200 mesh) with EtOAc-petroleum ether $\left(60-90{ }^{\circ} \mathrm{C}\right)$ as the eluent. Solutions were concentrated at $<60{ }^{\circ} \mathrm{C}$ under reduced pressure.

\section{2. (2R,3R)-1,3-Di-O-benzyl-4-pentene-1,2,3-triol (5)}

To a solution of compound $3(660 \mathrm{mg}, 2 \mathrm{mmol})$ in $\mathrm{MeOH}(10 \mathrm{~mL})$ was added $\mathrm{NaIO}_{4}(642 \mathrm{mg}$ in $5 \mathrm{~mL}$ $\mathrm{H}_{2} \mathrm{O}, 3 \mathrm{mmol}$ ). The mixture was stirred at room temperature and monitored by TLC (2:1 petroleum etherEtOAc) until all starting materials disappeared. The mixture was then filtered, and the filtrate was extracted with $\mathrm{CH}_{2} \mathrm{Cl}_{2}(2 \times 15 \mathrm{~mL})$. The combined organic phase was dried over anhyd $\mathrm{Na}_{2} \mathrm{SO}_{4}$ and concentrated to give syrupy (2S,3R)-2,4-bis(benzyloxy)-3-hydroxybutanal (4), which was directly used for the next reaction without purification. To a pre-cooled $\left(-40^{\circ} \mathrm{C}\right)$ solution of Wittig salt $\mathrm{CH}_{3} \mathrm{Ph}_{3} \mathrm{P}^{+} \mathrm{Br}^{-}(1.07 \mathrm{~g}, 3 \mathrm{mmol})$ in THF $(25 \mathrm{~mL})$ was slowly added $n$-BuLi $(2.5 \mathrm{M}$ in hexane, $2 \mathrm{~mL}, 5 \mathrm{mmol}$ ) under $\mathrm{N}_{2}$ protection. The orange mixture was stirred under these conditions for about $20 \mathrm{~min}$, then a solution of the above 4 in dry THF $(5 \mathrm{~mL})$ was added dropwise under $\mathrm{N}_{2}$ protection. The mixture was stirred at this temperature for another $30 \mathrm{~min}$, then allowed to warm up to room temperature. The progress of the reaction was monitored by TLC (2:1 petroleum
ether-EtOAc) until all starting materials disappeared. The reaction was quenched by satd $\mathrm{NH}_{4} \mathrm{Cl}(0.2 \mathrm{~mL})$, then diluted with water and extracted with EtOAc $(3 \times 20 \mathrm{~mL})$. The combined organic phase was dried over anhyd $\mathrm{Na}_{2} \mathrm{SO}_{4}$ and concentrated to dryness. Purification of the residue by silica gel column chromatography (3:1 petroleum ether-EtOAc) gave $5(489 \mathrm{mg}, 82 \%$ for two steps) as a syrup: $[\alpha]_{\mathrm{D}}^{25}-21\left(c 1, \mathrm{CHCl}_{3}\right) ;{ }^{1} \mathrm{H}$ NMR $\left(400 \mathrm{MHz}, \mathrm{CDCl}_{3}\right): \delta 2.70(\mathrm{~d}, 1 \mathrm{H}, J 3.9 \mathrm{~Hz})$, $3.50(\mathrm{dd}, 1 \mathrm{H}, J 5.5,10.0 \mathrm{~Hz}), 3.58(\mathrm{dd}, 1 \mathrm{H}, J 3.9$, $10.0 \mathrm{~Hz}), 3.76-3.80(\mathrm{~m}, 1 \mathrm{H}), 3.92(\mathrm{t}, 1 \mathrm{H}, J 6.7 \mathrm{~Hz})$, $4.36,4.63(2 \mathrm{~d}, 2 \mathrm{H}, J=11.6 \mathrm{~Hz}), 4.50,4.55(2 \mathrm{~d}, 2 \mathrm{H}$, $J=12.0 \mathrm{~Hz}), 5.32-5.36(\mathrm{~m}, 2 \mathrm{H}), 5.74-5.83(\mathrm{~m}, 1 \mathrm{H})$, 7.25-7.36 (m, 10H). Anal. Calcd for $\mathrm{C}_{19} \mathrm{H}_{22} \mathrm{O}_{3}$ : C, 76.48; H, 7.43. Found: C, 76.81; H, 7.36.

\section{3. $(2 R, 3 S, 4 R)-3-$ Benzyloxy-2-(iodomethyl)tetrahydro- furan-4-ol (6)}

To a solution of $5(220 \mathrm{mg}, 0.74 \mathrm{mmol})$ in anhyd $\mathrm{CH}_{3} \mathrm{CN} \quad(10 \mathrm{~mL})$ was added $\mathrm{NaHCO}_{3}(186 \mathrm{mg}$, $2.2 \mathrm{mmol}$ ). The mixture was stirred at $0{ }^{\circ} \mathrm{C}$ for $5 \mathrm{~min}$, and then iodine $(560 \mathrm{mg}, 2.2 \mathrm{mmol})$ was added. The reaction was monitored by TLC (2:1 petroleum etherEtOAc). After completion, the mixture was diluted with EtOAc and washed with aq sodium thiosulfate. The combined organic phase was dried over anhyd $\mathrm{Na}_{2} \mathrm{SO}_{4}$ and concentrated under vacuum to give a diastereomeric mixtrue. Purification of the mixtures by silica gel column chromatography (2:1 petroleum ether-EtOAc) gave pure compound $6(197 \mathrm{mg}, 80 \%)$ as a syrup: $[\alpha]_{\mathrm{D}}^{25}+78$ (c $\left.1, \mathrm{CHCl}_{3}\right) ;{ }^{1} \mathrm{H}$ NMR (400 MHz, $\left.\mathrm{CDCl}_{3}\right): \delta 1.65$ (br $\mathrm{s}, 1 \mathrm{H}), 3.28(\mathrm{dd}, 1 \mathrm{H}, J 6.0,9.3 \mathrm{~Hz}), 3.36(\mathrm{t}, 1 \mathrm{H}, J$ $9.3 \mathrm{~Hz}), 3.82(\mathrm{~d}, 1 \mathrm{H}, J 9.9 \mathrm{~Hz}), 4.00(\mathrm{~d}, 1 \mathrm{H}, J 3.7 \mathrm{~Hz})$, $4.20(\mathrm{dd}, 1 \mathrm{H}, J 3.9,9.9 \mathrm{~Hz}), 4.39-4.44(\mathrm{~m}, 2 \mathrm{H}), 4.62$, $4.67(2 \mathrm{~d}, 2 \mathrm{H}, J 11.4 \mathrm{~Hz}), 7.32-7.37(\mathrm{~m}, 5 \mathrm{H})$. Anal. Calcd for $\mathrm{C}_{12} \mathrm{H}_{15} \mathrm{IO}_{3}$ : C, 43.13; H, 4.52. Found $\mathrm{C}, 43.31 ; \mathrm{H}$, 4.42 .

\section{4. (2R,3S,4R)-3-(Benzyloxy)-4-hydroxytetrahydro- furan-2-carbaldehyde (7)}

To a mixture of DMSO $(5 \mathrm{~mL})$ and $\mathrm{NaHCO}_{3}(400 \mathrm{mg})$ at $150{ }^{\circ} \mathrm{C}$ under $\mathrm{N}_{2}$ protection was added compound $\mathbf{6}$ (170 $\mathrm{mg}, 0.51 \mathrm{mmol}$ ). The mixture was stirred at $150{ }^{\circ} \mathrm{C}$ for $5 \mathrm{~min}$, and then rapidly cooled to room temperature. The mixture was poured into ice water and extracted with $\mathrm{Et}_{2} \mathrm{O}(3 \times 10 \mathrm{~mL})$. The combined organic phase was dried over anhyd $\mathrm{Na}_{2} \mathrm{SO}_{4}$ and concentrated to dryness. Purification of the residue by silica gel column chromatography (2:1 petroleum ether-EtOAc) gave aldehyde 7 , which was directly used in the next step without further purification. A small sample was purified on a silica gel column to provide analytically pure 7: $[\alpha]_{\mathrm{D}}^{25}+64\left(c 1, \mathrm{CHCl}_{3}\right) ;{ }^{1} \mathrm{H}$ NMR $\left(400 \mathrm{MHz}, \mathrm{CDCl}_{3}\right)$ : $\delta 1.80$ (br s, 1H), 3.95 (d, 1H, J 10.0 Hz), 4.28-4.31 (m, 
$2 \mathrm{H}), 4.41(\mathrm{~d}, 1 \mathrm{H}, J 3.3 \mathrm{~Hz}), 4.51(\mathrm{dd}, J 1.7,4.9 \mathrm{~Hz}), 4.53$, $4.60(2 \mathrm{~d}, 2 \mathrm{H}, J 11.9 \mathrm{~Hz}), 7.25-7.37(\mathrm{~m}, 5 \mathrm{H}), 9.58(\mathrm{~d}, 1 \mathrm{H}$, $J 1.8 \mathrm{~Hz}) .{ }^{13} \mathrm{C}$ NMR $\left(100 \mathrm{MHz}, \mathrm{CDCl}_{3}\right): \delta 72.5,74.4$, $75.0,84.6,85.9,127.6,127.9,128.4,136.9,201.0$. HRFABMS: Calcd for $\mathrm{C}_{12} \mathrm{H}_{14} \mathrm{O}_{4}$ : 222.0892. Found: $223.0878(\mathrm{M}+\mathrm{H})^{+}$.

\section{5. (2R,3S,4R)-3-(Benzyloxy)-4-methanesulfonyloxy- tetrahydrofuran-2-carbaldehyde (8)}

To a solution of crude $7(0.51 \mathrm{mmol})$ in pyridine $(2 \mathrm{~mL})$ was added methanesulfonyl chloride $(90 \mu \mathrm{L}, 1.2 \mathrm{mmol})$. The mixture was stirred at room temperature for $30 \mathrm{~min}$, and then co-evaporated with toluene under vacuum. Purification of the residue by silica gel column chromatography (1:1 petroleum ether-EtOAc) gave $8(113 \mathrm{mg}$, $74 \%$ for two steps) as a syrup: $[\alpha]_{\mathrm{D}}^{25}+27\left(c 0.4, \mathrm{CHCl}_{3}\right)$; ${ }^{1} \mathrm{H}$ NMR $\left(400 \mathrm{MHz}, \mathrm{CDCl}_{3}\right): \delta 2.94(\mathrm{~s}, 3 \mathrm{H}), 4.10(\mathrm{~d}, 1 \mathrm{H}$, $J 11.1 \mathrm{~Hz}), 4.28(\mathrm{dd}, 1 \mathrm{H}, J 3.5,11.1 \mathrm{~Hz}), 4.44(\mathrm{~d}, 1 \mathrm{H}, J$ $4.6 \mathrm{~Hz}), 4.50,4.60(2 \mathrm{~d}, 2 \mathrm{H}, J 11.9 \mathrm{~Hz}), 4.57(\mathrm{~d}, 1 \mathrm{H}, J$ $4.9 \mathrm{~Hz}), 5.12(\mathrm{~d}, 1 \mathrm{H}, J 3.1 \mathrm{~Hz}), 7.21-7.31(\mathrm{~m}, 5 \mathrm{H}), 9.53$ (s, 1H). ${ }^{13} \mathrm{C}$ NMR $\left(100 \mathrm{MHz}, \mathrm{CDCl}_{3}\right): \delta 37.9,71.8$, 72.2, 80.6, 82.9, 83.9, 127.5, 127.9, 128.2, 136.1, 198.7. HRFABMS: Calcd for $\mathrm{C}_{13} \mathrm{H}_{16} \mathrm{O}_{6} \mathrm{~S}$ : 300.0668; Found: $301.0685(\mathrm{M}+\mathrm{H})^{+}$.

\section{6. $(3 R, 4 R, 5 S)-4-($ Benzyloxy)-5-((E,Z)-tetradec-1-enyl)- tetrahydrofuran-3-yl methanesulfonate $(9)$}

To a pre-cooled $\left(-40^{\circ} \mathrm{C}\right)$ solution of the Wittig salt $\mathrm{C}_{13} \mathrm{H}_{27} \mathrm{Ph}_{3} \mathrm{P}^{+} \mathrm{Br}^{-}(884 \mathrm{mg}, 1.68 \mathrm{mmol})$ in anhyd THF $(25 \mathrm{~mL})$ was slowly added $n$-BuLi $(2.5 \mathrm{M}$ in hexane, $0.67 \mathrm{~mL}, 1.68 \mathrm{mmol}$ ) under $\mathrm{N}_{2}$ protection. The orange solution was stirred under these conditions for about $20 \mathrm{~min}$, and then a solution of $8(336 \mathrm{mg}, 1.12 \mathrm{mmol})$ in dry THF $(3 \mathrm{~mL})$ was added dropwise under $\mathrm{N}_{2}$ protection. The mixture was stirred at this temperature for another $30 \mathrm{~min}$, and then allowed to warm up to room temperature. The reaction was monitored by TLC (3:1 petroleum ether-EtOAc) until all starting materials disappeared. The reaction was then quenched by satd $\mathrm{NH}_{4} \mathrm{Cl}(0.2 \mathrm{~mL})$, and the mixture was diluted with water and extracted with EtOAc $(3 \times 20 \mathrm{~mL})$. The combined organic phase was dried over anhyd $\mathrm{Na}_{2} \mathrm{SO}_{4}$ and concentrated to dryness. Purification of the residue by silica gel column chromatography $(3: 1$ petroleum ether-EtOAc) gave 9 (470 mg, 90\%, Z/E>10:1, determined by ${ }^{1} \mathrm{H}$ NMR) as a syrup: Selected ${ }^{1} \mathrm{H}$ NMR $\left(400 \mathrm{MHz}, \mathrm{CDCl}_{3}\right)$ for the $Z$-isomer: $\delta 0.88(\mathrm{t}, 3 \mathrm{H}, J$ $7.1 \mathrm{~Hz}$ ), 1.27 (br s, 20H), 2.07-2.13 (m, 2H), 2.99 (s, $3 \mathrm{H}), 3.98(\mathrm{dd}, 1 \mathrm{H}, J 1.9,10.9 \mathrm{~Hz}), 4.08(\mathrm{~d}, 1 \mathrm{H}, J$ $3.9 \mathrm{~Hz}), 4.29$ (dd, 1H, J 4.9, $10.9 \mathrm{~Hz}), 4.64(2 \mathrm{~d}, 2 \mathrm{H}, J$ $12.1 \mathrm{~Hz}), 4.77(\mathrm{dd}, 1 \mathrm{H}, J 3.9,8.3 \mathrm{~Hz}), 5.16(\mathrm{~d}, 1 \mathrm{H}, J$ $4.7 \mathrm{~Hz}), 5.63-5.77(\mathrm{~m}, 2 \mathrm{H}), 7.29-7.35(\mathrm{~m}, 5 \mathrm{H}) .{ }^{13} \mathrm{C}$ NMR $\left(100 \mathrm{MHz}, \mathrm{CDCl}_{3}\right): \delta 14.0,22.6,27.9,29.1$, $29.2,29.3,29.4,29.5,29.6,31.8,38.3,70.5,72.3,76.0$,
82.6, 82.9, 123.3, 127.7, 127.9, 128.4, 135.7, 137.2. Anal. Calcd for $\mathrm{C}_{26} \mathrm{H}_{42} \mathrm{O}_{5} \mathrm{~S}: \mathrm{C}, 66.92 ; \mathrm{H}, 9.07$. Found: C, 67.15; H, 8.98.

\section{7. (2S,3S,4S)-4-Azido-3-(benzyloxy)-2-((E,Z)-tetradec- 1-enyl)tetrahydrofuran (10)}

To a solution of 9 ( $47 \mathrm{mg}, 0.1 \mathrm{mmol}, Z, E$ mixture) in dry DMF $(5 \mathrm{~mL})$ was added $\mathrm{NaN}_{3}(39 \mathrm{mg}, 0.6 \mathrm{mmol})$ and anhyd $\mathrm{NH}_{4} \mathrm{Cl}(107 \mathrm{mg}, 0.2 \mathrm{mmol})$. The mixture was heated to $120^{\circ} \mathrm{C}$ and stirred for about $20 \mathrm{~h}$ in a dark room. The reaction was monitored by TLC (4:1 petroleum ether-EtOAc) until all starting materials disappeared, then the mixture was diluted with water and extracted with EtOAc $(4 \times 8 \mathrm{~mL})$. The organic phase was dried over anhyd $\mathrm{Na}_{2} \mathrm{SO}_{4}$ and concentrated. Purification of the residue by silica gel column chromatography ( $4: 1$ petroleum ether-EtOAc) gave $10(33 \mathrm{mg}, 80 \%$, $Z, E$ mixture) as a syrup: Selected ${ }^{1} \mathrm{H}$ NMR $(400 \mathrm{MHz}$, $\mathrm{CDCl}_{3}$ ) for the $Z$ isomer: $\delta 0.88(\mathrm{t}, 3 \mathrm{H}, J 7.1 \mathrm{~Hz}), 1.20$ (br s, 20H), 2.07-2.09 (m, 2H), 3.88-3.97 (m, 3H), 4.11 $(\mathrm{t}, 1 \mathrm{H}, J 5.0 \mathrm{~Hz}), 4.62,4.70(2 \mathrm{~d}, 2 \mathrm{H}, J 11.8 \mathrm{~Hz}), 4.71-$ $4.72(\mathrm{~m}, 1 \mathrm{H}), 5.65-5.73(\mathrm{~m}, 2 \mathrm{H}, J 11.0 \mathrm{~Hz}), 7.29-7.37$ $(\mathrm{m}, 5 \mathrm{H}) .{ }^{13} \mathrm{C}$ NMR $\left(100 \mathrm{MHz}, \mathrm{CDCl}_{3}\right): \delta 14.0,22.6$, $27.7,29.2,29.3,29.4,29.5,29.6,31.8,61.5,68.6,73.3$, $75.8,80.4,124.9,127.7,127.8,128.3,135.0,137.4$. HRFABMS: Calcd for $\mathrm{C}_{25} \mathrm{H}_{39} \mathrm{~N}_{3} \mathrm{O}_{2}$ : 413.3042. Found: $414.3068(\mathrm{M}+\mathrm{H})^{+}$.

\subsection{Synthesis of jaspine B (1)}

To a mixture of olefin $\mathbf{1 0}(210 \mathrm{mg}, 0.5 \mathrm{mmol})$ and Pd/C $(10 \%$ content, $50 \mathrm{mg})$ in $\mathrm{MeOH}(50 \mathrm{~mL}$, containing $1 \%$ of TFA) $\mathrm{H}_{2}$ was bubbled in at a flow rate of $100 \mathrm{~mL} /$ min under room temperature and $4 \mathrm{~atm}$ pressure. (Caution! Extreme fire hazard!) The hydrogenation was kept at these conditions for about $5 \mathrm{~h}$, at the end of which time, TLC (4:1 EtOAc-MeOH) showed only one product generated. The $\mathrm{Pd} / \mathrm{C}$ was filtered, and the filtrate was concentrated. The residue was purified on a short silica gel column using 4:1 EtOAc- $\mathrm{MeOH}$ as eluent to furnish target compound $1(145 \mathrm{mg}, 95 \%)$ as a white solid in salt form: $[\alpha]_{\mathrm{D}}^{25}+11\left(c 1, \mathrm{CHCl}_{3}\right) ;{ }^{1} \mathrm{H}$ NMR (400 MHz, CD $\left.\mathrm{CD}_{3} \mathrm{OD}\right): \delta 0.89(\mathrm{t}, 3 \mathrm{H}, J 7.0 \mathrm{~Hz})$, $1.26-1.45(\mathrm{~m}, 24 \mathrm{H}), 1.60-1.65(\mathrm{~m}, 2 \mathrm{H}), 3.70(\mathrm{dt}, 1 \mathrm{H}$, $J 3.5,6.8 \mathrm{~Hz}$ ), 3.79 (dd, $1 \mathrm{H}, J 4.8,7.9 \mathrm{~Hz}), 3.82-3.93$ $(\mathrm{m}, 2 \mathrm{H}), 4.23(\mathrm{dd}, 1 \mathrm{H}, J 3.5,4.8 \mathrm{~Hz}) .{ }^{13} \mathrm{C}$ NMR $\left(100 \mathrm{MHz}, \mathrm{CD}_{3} \mathrm{OD}\right): \delta 14.5,23.7,27.2,29.7,30.5$, 30.7, 30.8, 30.9, 33.1, 54.3, 68.9, 70.9, 84.4. HRFABMS: Calcd for $\mathrm{C}_{18} \mathrm{H}_{37} \mathrm{NO}_{2}$ (after co-evaporation with $\left.\mathrm{NH}_{4} \mathrm{OH}\right)$ : 299.2824. Found: $300.2856(\mathrm{M}+\mathrm{H})^{+}$.

\subsection{Bioassay}

Human MDA231, CNE, and HeLa cells $\left(3 \times 10^{5} /\right.$ well $)$ were cultured in a suspension of Dulbcco's Modified 
Eagle Medium (DMEM) supplemented with 10\% newborn calf serum, $100 \mathrm{kU} / \mathrm{mL}$ of penicillin and $100 \mathrm{mg} /$ $\mathrm{mL}$ of streptomycin in a humidified atmosphere of $5 \%$ $\mathrm{CO}_{2}$ at $37^{\circ} \mathrm{C}$. Exponentially growing tumor cells at $1 \times 10^{5}$ cells $/ \mathrm{mL}$ in culture were treated with jaspine $\mathrm{B}$ at a concentration of $0.005,0.01,0.1$, and $1 \mu \mathrm{g} / \mathrm{L}$ for 24,48 , and $72 \mathrm{~h}$, respectively. The positive control cultures were treated with CDDP at $3 \mu \mathrm{g} / \mathrm{mL}$ under the same conditions, while the negative control cultures (DMEM) were left untreated at $37^{\circ} \mathrm{C}$ for the same period of time. The number of viable cells was determined by the acid phosphatase assay (APA), and the percentage inhibition of cell proliferation was calculated by the following formula: Inhibition $\%=\left[1-\left(\mathrm{OD}_{405 \mathrm{~nm}}\right.\right.$ for experimental group/ $\mathrm{OD}_{405 \mathrm{~nm}}$ for control group)] $\times$ $100 \%$.

\section{Acknowledgments}

This work was supported by the National Basic Research Program of China (2003CB415001) and NNSF of China (30330690).

\section{Supplementary data}

Supplementary data (images of NMR spectra for compounds) associated with this article can be found, in the online version, at doi:10.1016/j.carres.2006.08.011.

\section{References}

1. Jenkins, G. M. Cell. Mol. Life Sci. 2003, 60, 701-710.

2. (a) Vasta, V.; Meacci, E.; Catarzi, S.; Donati, C.; Farnararo, M.; Bruni, P. Biochim. Biophys. Acta 2000, 1483, 154-160; (b) Meacci, E.; Vasta, V.; Moorman, J. P.; Bobak, D. A.; Bruni, P.; Moss, J.; Vaughan, M. J. Biol. Chem. 1999, 274, 18605-18612.
3. Liao, J.; Tao, J.; Lin, G.; Liu, D. Tetrahedron 2005, 61, 4715-4733.

4. (a) Shibano, M.; Tsukamoto, D.; Kusano, G. Heterocycles 2002, 57, 1539-1553; (b) Lynch, D. V.; Dunn, T. M. New Phytol. 2004, 161, 677-702; (c) Dickson, R. C.; Lester, R. L. Biochim. Biophys. Acta 1999, 1438, 305-321.

5. Sudhakar, N.; Kumar, A. R.; Prabhakar, A.; Jagadeesh, B.; Rao, B. V. Tetrahedron Lett. 2005, 46, 325-327.

6. (a) Kuroda, I.; Musman, M.; Ohtani, I. I.; Ichiba, T.; Tanaka, J.; Cravalos, D. C.; Higa, T. J. Nat. Prod. 2002, 65, 1505-1506; (b) Ledroit, V.; Debitus, C.; Lavaud, C.; Massiot, G. Tetrahedron Lett. 2003, 44, 225-228.

7. (a) Sudhakar, N.; Kumar, A. R.; Prabhakar, A.; Jagadeesh, B.; Rao, B. V. Tetrahedron Lett. 2005, 46, 325-327; (b) Bhaket, P.; Morris, K.; Stauffer, C. S.; Datta, A. Org. Lett. 2005, 7, 875-876; (c) Bhaket, P.; Stauffer, C. S.; Datta, A. J. Org. Chem. 2004, 69, 8594-8601; (d) Du, Y.; Liu, J.; Linhardt, R. J. J. Org. Chem. 2006, 71, 1251-1253; (e) van den Berg, R. J. B. H. N.; Boltje, T. J.; Verhagen, C. P.; Litjens, R. E. J. N.; van der Marel, G. A.; Overkleeft, H. S. J. Org. Chem. 2006, 71, 836-839; (f) Ribes, C.; Falomir, E.; Carda, M.; Marco, J. A. Tetrahedron 2006, 62, 5421-5425; (g) Chandrasekhar, S.; Tiwari, B.; Prakash, S. J. ARKIVOC 2006, 11, 155-161.

8. (a) Du, Y.; Kong, F. Tetrahedron Lett. 1995, 36, 427-430; (b) Du, Y.; Kong, F. J. Carbohydr. Chem. 1995, 14, 341352.

9. Bravo, F.; Castillon, S. Eur. J. Org. Chem. 2001, 507-516.

10. (a) Kang, S. H.; Lee, S. B. Tetrahedron Lett. 1993, 34, 7579-7582; (b) Rychnovsk, S. D.; Bartlett, P. A. J. Am. Chem. Soc. 1981, 103, 3963-3964; (c) Bravo, F.; Diaz, Y.; Castillon, S. Tetrahedron: Asymmetry 2001, 12, 16351643; (d) Peri, F.; Cipolla, L.; Ferla, B. L.; Nicotra, F. Chem. Commun. (Cambridge) 2000, 2303-2304.

11. Johnson, A. P.; Pelter, A. J. Chem. Soc. 1964, 520-522.

12. (a) Muralidhar, P.; Radhika, P.; Krishna, N.; Rao, D. V.; Rao, C. B. Nat. Prod. Sci. 2003, 9, 117-142; (b) Jo, S. Y.; Kim, H. C.; Jeon, D. J.; Kim, H. R. Heterocycles 2001, 55, 1127-1132; (c) Bols, M. Acc. Chem. Res. 1998, 31, 1-8; (d) Asano, N.; Nash, R. J.; Molyneux, R. J.; Fleet, G. W. J. Tetrahedron: Asymmetry 2000, 11, 1645-1680; (e) Callam, C. S.; Lowary, T. L. J. Org. Chem. 2001, 66, 8961-8972; (f) Bleriot, Y.; Giroult, A.; Mallet, J.-M.; Rodriguez, E.; Vogel, P.; Sinaÿ, P. Tetrahedron: Asymmetry 2002, 13, 2553-2565. 